\title{
Effects of soya-bean products on digestive processes in the gastrointestinal tract of preruminant calves
}

\section{By J. W. Sissons, National Institute for Research in Dairying, Shinfield, Reading $R G_{2} g A T$}

It is well established that crudely processed soya beans are unsuitable as a source of protein for the young calf. Early studies showed that replacing milk protein with finely ground soya beans in liquid diets for calves led to excessive diarrhoea, loss of appetite, muscular weakness, high mortality and poor growth amongst surviving animals (Shoptaw, 1936; Williams \& Knodt, 1950). Later trials attempted to improve growth by removing oil, known to be poorly utilized by the calf (Raven, 1970), from soya-bean meal, but this treatment did not lead to any notable improvement (Stein et al. 1954; Lassiter et al. 1959). Methionine supplementation of soya-bean protein in calf diets to correct a possible deficiency of sulphur amino acids also failed to produce a growth response (Gorrill \& Nicholson, 1969).

Attention then turned to the possible anti-nutritional effects of 'biologically active' proteins, such as protease inhibitors and haemagglutinins, shown to be nutritionally harmful to monogastric animals (Rackis et al. 1963; Stead et al. 1966; Gertler \& Nitsan, 1970). However, even after treating defatted soya-bean meal with steam to inactivate these anti-nutritional substances (Rackis, 1966; Circle \& Smith, 1972) the nutritive value of the product remained markedly inferior to milk protein for the calf (Gorril \& Thomas, 1967; Nitsan et al. 1972; Kwiatkowska, 1973).

Recently, several studies embracing the fields of nutrition, digestive physiology and immunology have provided some understanding of the nature of soya bean intolerance in calves. This review will consider these investigations and discuss the idea that calves reared on liquid diets containing unrefined soya-bean products may suffer from gastrointestinal hypersensitive reactions involving major disturbances in digestive functions.

\section{Development of intolerance to soya-bean products}

The ability of an animal to utilize nutrients from a wide variety of sources is likely to depend upon the capacity of its gastrointestinal tract to adapt to new conditions. Thus, the digestive system may require mechanisms to recognize variations in physical and chemical properties of different feedstuffs, to adjust processes for the synthesis and secretion of sufficient quantities of suitable enzymes, to control motile functions for mixing and transferring digesta along the alimentary tract according to the state of digestion, to destroy anti-nutritional substances having inhibitory effects on enzyme activities and to protect tissues of the gut wall against damage by 'immunologically active' constituents. It is possible 
that in calves fed on certain soya-bean products such adaptive mechanisms either fail or are absent.

Digestive processes. Calves cannulated in different sites of the gastrointestinal tract and given a succession of liquid feeds containing fat-free and heated soyabean flour often developed abnormalities in digesta movement and nutrient absorption (Smith \& Sissons, 1975; Sissons \& Smith, 1976). These disorders were not observed on the first occasion that heated soya-bean flour was given, but developed progressively with successive feeds. They included inhibition of abomasal digesta outflow to the duodenum, decreased transit time of digesta passage through the small intestine, increased flow of water, sodium and potassium at the distal ileum and decreased absorption of nitrogen. From interrelations between these disturbances it seems possible that the first effect is a reduction in transit time through the small intestine. Once this is below a critical time of about $2 \mathrm{~h}$, marked decreases in nitrogen absorption occur and possibly absorption of other dietary constituents such as magnesium may be affected (Smith, 1963). Decreased nutrient absorption may then, in turn, lead to increased flow of ileal digesta, largely because of osmotic effects due to the presence of poorly digested dietary constituents in the gut lumen. Variations in amounts of osmotically active substances have been associated with changes in volumes of fluids passing to the large intestine of calves given whole milk feeds (Smith, I966; Coombe, 1972).

Immunological responses. Severe digestive disturbances were found to occur in calves receiving defatted soya-bean flour only when the animals were given a series of feeds containing this product. This led to speculation that they were sensitized by the first feeds and then developed a gastrointestinal allergy to some factor present in the soya-bean (Smith \& Sissons, 1975; Sissons \& Smith, 1976). Support for this idea was given by the detection of IgG antibodies specific for soya-bean globulins, mainly glycinin and $\beta$-conglycinin, in the serum of calves fed on soyabean protein (Smith \& Sissons, 1975; Barratt et al. 1978; Kilshaw \& Sissons, 1979a; Kilshaw \& Slade, 1980). But although levels of serum antibodies against soya-bean protein sometimes showed a broad relationship to the severity of disorders in digesta movement and growth performance of calves given feeds containing soya-bean flour or isolate (van Leeuwen et al. 1969; Kilshaw \& Sissons, 1979a) the mechanism of the relationship is not clear.

It has been suggested by Barratt et al. (1978) that hypersensitive reactions to soya-bean products occur in calves because of possible failings of immuno-defence mechanisms of the gut. These workers reported that in the young calf the synthesis of secretory immunoglobulins, IgA and IgM against soya-bean antigens, in the intestinal mucosa was low (Barratt \& Porter, 1979). Thus, secretion of these immunoglobulins may be insufficient to prevent the absorption of intact or partially digested soya-bean protein and the consequent stimulation of the systemic immune system. Barratt et al. (1979) have postulated that the disturbances in digestive processes are due to the formation of complexes between soya-bean antigens and systemic IgG antibody, and activation of the complement 
system leading to increased vascular permeability and tissue damage (known as type 3 complex-mediated hypersensitivity (Roitt, 1974)). This view is supported by some histological studies of the intestinal mucosa of calves given soya-bean products that provided evidence of tissue inflammatory responses; biopsy samples showed villous atrophy, oedema and lymphocytic infiltration (Roy et al. 1977; Barratt et al. 1978) similar to the morphological changes observed in the gut of a human infant showing soya-bean protein intolerance (Ament \& Rubin, I972).

Immunological mechanisms leading to gastrointestinal disturbances may also involve reaginic antibodies. In some calves showing sensitivity to feeds containing heated soya-bean flour IgE antibodies were detected in the serum (Kilshaw \& Sissons, I979a). The presence of these reagins, which are indicative of type I anaphylactic hypersensitivity (Roitt, 1974) corresponded to increases in the flow of ileal digesta. These antibodies may have been associated with some particularly severe changes in gastric motility and gut permeability in highly sensitive calves. For example, inhibition of gastric emptying was sometimes observed to occur within $30 \mathrm{~min}$ of a calf receiving a feed of heated soya-bean flour (Smith \& Sissons, 1975). In other animals tubular fibrin casts were extruded from an ileal cannula within $\mathrm{I} h$ of giving a soya-bean flour feed suggesting that a dramatic increase in vascular permeability of the small intestine had resulted in large amounts of plasma protein entering the lumen (Kilshaw \& Sissons, 1979a).

It should be emphasized that there is considerable variation between calves in the extent to which they show hypersensitive responses to soya-bean flour (Sissons \& Smith, 1976; Kilshaw \& Sissons, 1979a). A few calves (approximately 10\%) seem to be unaffected by these products. Although the reason for this tolerance is unknown, it may be that hypersensitivity to soya-bean products is related to the earlier immunological and nutritional status of the calf and also its dam.

There are some reports in the literature of human adults and infants who showed hypersensitive reactions from ingestion or inhalation of soya-bean products (Vest, 1953; Ratner et al. 1955; Mortimer, 1959; Cook, 1960; Perlman, 1966; Ament \& Rubin, 1972; Albert, 1979; Gunn et al. 1980). These subjects suffered from a variety of symptoms including anaphylactic shock, violent gastrointestinal reactions, such as vomiting and diarrhoea, and rapid loss of weight. Some of them also showed high titres of circulatory antibodies against soya-bean products. In contrast, other workers have shown that soya-bean 'milk' prepared from isolated soya-bean protein is usually a satisfactory food for infants allergic to human and cow's milk provided that the product is properly heated to inactivate trypsin inhibitor (Glaser \& Johnstone, 1953; Vest et al. 1966; Sellars et al. 1971).

\section{Disturbances in gastrointestinal motility and secretion}

Abomasal emptying. Although the process by which heated soya-bean flour inhibits abomasal emptying has not been thoroughly studied, there is some evidence suggesting that the hold-up is mediated by changes in the composition of duodenal digesta (Sissons \& Smith, 1978). For example, duodenal infusates of 
solutions containing heated soya-bean flour were shown to have an inhibitory effect on the abomasal emptying rate of a casein based liquid feed in calves previously sensitized to soya-bean protein.

It has been demonstrated in man and the dog that stomach emptying is inhibited by digestion products of protein and fat entering the duodenum and by low $\mathrm{pH}$ at that site (Quigley \& Mescham, 1941; Thomas, I942; Hunt \& Knox, 1 968; Erbersdobler, I973; Stephens et al. 1975). There is also evidence that these factors have similar effects on abomasal emptying in the calf (Bush et al. 1963; Tagari \& Roy, I969; Bell \& Mostaghni, I975; Bell \& McLeay, I978). However, it is unlikely that these constituents were responsible for the apparent inhibition of abomasal motor function in calves given soya-bean flour feeds as digesta entering the duodenums of these animals contained less acid and digested protein than did comparable digesta in milk fed calves (Gorrill \& Thomas, 1967; Smith \& Sissons, 1975; Ternouth et al. 1975).

Another factor to be considered as having a possible influence on the movement of digesta from the abomasum of calves given soya-bean flour is trypsin inhibitor. In rats, stomach emptying of a test feed containing a crude preparation of soyabean trypsin inhibitor or one containing raw soya-bean meal was slower than that of a feed containing heated soya-bean meal (de Meulenaere, 1964; Erbersdobler, 1973). But, these findings were not supported by studies in calves in which feeds containing soya-bean flours differing greatly in trypsin activity all left the abomasum at about the same rate (Smith \& Sissons, 1975).

The inability of soya-bean products to form a clot in the abomasum may affect the passage of protein to the small intestine and its subsequent digestion. Lack of coagulation might be expected to result in a relatively rapid flow of poorly digested nitrogenous compounds to the duodenum soon after feeding. However, the extent to which this occurs seems to depend partly on the solubility of the product and also on any effects on gastric motility. Thus, in studies of abomasal digesta flow in calves, nitrogenous compounds of an insoluble isolated soya-bean protein were selectively retained relative to water soluble constituents (Smith \& Sissons, 1975), whereas protein of soya-bean flour solubilized with alkali entered the duodenum fairly rapidly after feeding (Ternouth et al. 1975). This is in contrast to the apparent inhibitory effects on gastric motility of a series of heated, but otherwise untreated, soya-bean flour feeds involving the abomasal hold-up of all dietary constituents (Smith \& Sissons, 1975). Whilst it is unlikely that this slowing of abomasal emptying has any notable effect on nutrient utilization, the inhibitory process is probably part of the wider disorders affecting the function of the small intestine.

Intestinal motor activity. Electromyographic studies in the calf, dog and sheep have shown that the movement of digesta through the small intestine is accompanied by complex muscular contractions occurring in the gut wall (Szurszewski, 1969; Ruckebusch \& Bueno, 1973; Bueno et al. 1975; Poncet, et al. 1977). In the fasting animal this muscular activity was observed to arise in the duodenum and propagate distally towards the lower intestine (Dardillat, 1977; 
Dardillat \& Marrero, I977). Recently, it was shown that replacing casein with heated soya-bean flour in a liquid feed given to calves resulted in an increase in the frequency of migratory myoelectric complexes along the small intestine together with disorders in the regular phase of spike potentials (Sissons \& Smith, r 979). It is possible that a constituent of soya-bean flour interferes with the mechanism which normally regulates the recurrent migrations of myoelectric activity. These gastrointestinal motor disturbances observed in calves fed on soya-bean flour showed similarities to those reported in sheep infested with nematodes and suffering from diarrhoea. In the sheep, frequencies of reticular and abomasal bulb contractions were depressed a few days before, and during, diarrhoea. At the same time migratory complexes were replaced by frequent, but irregular bursts of spike activity which rapidly propagated along the whole intestine (Bueno \& Fioramonti, 1979). It is noteworthy that in rats high levels of reaginic (IgE) antibodies are produced following infestation with helminth parasites (Jarrett \& Urquhart, 1971; Jarrett, 1973). These observations of disturbances in motor function and circulatory reaginic antibodies in animals infested with nematodes, together with similar findings in calves fed soya-bean flour, suggest that mechanisms leading to abnormal motility of gastrointestinal tract may possibly involve immunological factors.

There is no direct information on dietary constituents which specifically affect the motility of the calf intestine. Osmotic effects of poorly absorbed constituents may indirectly contribute to rapid transit of digesta. For example, in calves receiving soya-bean flour feeds dilution of gut contents by abnormally high volumes of intestinal secretions would be expected to increase the mobility of digesta.

Protease secretion. Limited studies have shown that peak activities of proteases in gastric and pancreatic secretion of preruminant calves are not achieved until animals are about I month of age (Gorrill et al. 1967; Ternouth et al. 1971; Henschel, 1973; Garnot et al. 1977). Also, there are reports that feeding heated soya-bean flour to calves depressed the flow of gastric and pancreatic juice and led to a reduction in protease activity of digesta and digestive secretions (Gorrill \& Thomas, 1967; Gorrill et al. 1967; Ternouth et al. 1975; Williams et al. 1976). It seems, therefore, that such limitations in the digestive capacity of the young calf probably contribute to the survival of immunologically active soya-bean protein in the gastrointestinal tract. Recently, an immunological study of enzymatic digests of commercial soya-bean products revealed that whilst pepsin readily destroyed the antigenic activity of glycinin, it did not affect $\beta$-conglycinin, and trypsin had little or no effect on either protein (Sissons, unpublished results). This stability of antigenic soya-bean globulins to proteolysis may explain the lack of improvement in growth performance of calves given milk replacers containing soya-bean products predigested or supplemented with proteases (Williams \& Knodt, I95 I ; Fries et al. 1958; Lassiter et al. 1959).

Gastrointestinal hormones. Neuroendocrine systems are believed to control many gastrointestinal processes (Polak \& Bloom, 1980). This concept is based 
mainly on studies in man and some monogastric animals, but there is some information suggesting that gut hormones are involved in regulating motile and secretory processes in the calf (Bell, I979). In calves receiving large amounts of soya-bean flour in their diet, synthesis of these endocrines, which occurs in mucosal cells (Polak \& Bloom, 1980), may be affected by tissue damage of the gut wall (Barratt et al. 1978). However, the distribution of gastrointestinal hormones in calves showing hypersensitive reactions to soya-bean products awaits investigation.

\section{Constituents responsible for digestive disorders}

Globular proteins. Glycinin and $\beta$-conglycinin, which are major globulins of soya-bean protein, have been identified as immunogenically active constituents responsible for provoking specific responses of serum IgG antibodies in calves showing sensitivity to soya-bean flour (Kilshaw \& Sissons, 1979a,b). An immunochemical survey of several commercial soya-bean products showed most samples to contain large amounts of these antigens. Such products included fatextracted and heated soya-bean flour, soya-bean concentrate prepared by water leaching of oligosaccharides and soya-bean protein isolate (Kilshaw \& Sissons, $1979 b$ ). In earlier studies, all of these products were found to cause disorders in digesta flow and nitrogen absorption in experimental calves (Sissons \& Smith, 1976).

Immunologically active glycinin and $\beta$-conglycinin were not detected in soyabean concentrate prepared by extracting oligosaccharides from soya-bean meal with hot aqueous ethanol. This finding is in agreement with observations that giving the same product to cannulated or intact calves did not result in disorders in digestive processes or in the development of serum antibodies against soya-bean protein (Smith \& Sissons, 1975; Sissons \& Smith, I 976). Moreover, in growth and digestibility trials calves given milk replacers containing commercial soya-bean concentrates prepared by ethanol extraction showed markedly better performances than animals receiving heated soya-bean flour (Gorrill \& Thomas, 1967; Gorrill \& Nicholson, 1969, 1972; Nitsan et al. 1971, 1972). In other experiments the absence of severe disturbances in digesta movement and $\mathrm{N}$ absorption in calves given feeds containing ethanol treated soya-bean products suggests that the alcohol inactivates, rather than extracts, the deleterious constituents (Sissons et al. r 979).

Oligosaccharides. It appears that the preruminant calf is not endowed with enzymes necessary for the digestion of soya-bean oligosaccharides, which consist of sucrose, raffinose and stachyose (Siddons, i 968 ; Besle \& Thivend, 1980). As a result these carbohydrates enter the large intestine where they are broken down by microbial fermentation. Studies in man and the dog have shown that gaseous endproducts arising from this process are responsible for diarrhoea, muscular cramp and flatulence (Steggerda et al. 1966; Rackis et al. 1970). Removal of oligosaccharides, known to be soluble in aqueous alcohol (Wolf, 1970) from soyabean meal may be responsible, in part, for the improved growth performance of calves given ethanol extracted soya-bean concentrates (Gorrill \& Nicholson, r969, 
I972; Nitsan et al. 1971, 1972). In a recent study with cannulated calves the addition of soya-bean molasses to feeds containing casein or soya-bean concentrate led to small increases in digesta flow and recoveries of dietary $\mathrm{N}$ at the distal ileum (Henschel and Sissons, unpublished results). These changes probably arose from osmotic effects of undigested carbohydrates in the lumen of the small intestine.

\section{Immunochemical assay of soya-bean products}

Observations indicating a general correlation between the immunogenic activity of glycinin and $\beta$-conglycinin in certain soya-bean products and the occurrence of digestive disorders implies that it might be possible to develop an in vitro immunochemical assay to predict the effectiveness of treatment conditions to remove allergenic constituents from soya beans. Recently, the allergenicity of several experimental soya-bean concentrates prepared under different conditions of alcohol concentration and temperatures were examined (Sissons et al. 1981). Levels of immunogenically active glycinin and $\beta$-conglycinin in different soya-bean products estimated by a haemagglutination inhibition test were positively related to the severity of gastrointestinal disorders caused by feeding the products to calves. Results showed that inactivation of immunogenic activity was dependent upon both concentration and temperature of aqueous alcohol. In a more recent study this activity was found to be minimal in products prepared by treatment with approximately $65 \%$ aqueous ethanol at $78^{\circ}$ (Sissons and Nyrup, unpublished results). These tests also indicated that small variations in either factor may lead to considerable differences in the antigenicity of the product.

\section{Conclusion}

From the available evidence it appears that some soya-bean products contain a factor which survives digestion in the abomasum and small intestine and, to varying degrees in different calves, causes abnormalities in digestive processes. Immunological hypersensitive reactions associated with these disturbances are probably provoked by antigenically active soya-bean proteins, glycinin and $\beta$-conglycinin. With these findings in mind there is a need to monitor the antigenicity of soya-bean products intended for calf feeding. In view of evidence of similar reactions occurring in man similar control may be needed for products used for 'extending' human foods.

Investigations are required to elucidate possible relationships between mechanisms of immunological hypersensitivity and abnormalities in motile and secretory processes of the gastrointestinal tract. For this purpose calves showing sensitivity to soya-bean flour may serve as a suitable model.

\section{REFERENCES}

Albert, R. (1979). Méd. et. Nut. 15, 327.

Ament, M. R. \& Rubin, C. E. (1972). Gastroenterology 62, 227.

Barratt, M. E. J. \& Porter, P. (I979). F. Immunol. 123, 676.

Barratt, M. E. J., Strachan, P. J. \& Porter, P. (1978). Clin. exp. Immunol. 31, 305.

Barratt, M. E. J., Strachan, P. J. \& Porter, P. (1979). Proc. Nutr. Soc. 38, 143. 
Bell, F. R. (1979). In Digestive Physiology and Metabolism in Ruminants, p. 8 I [Y. Ruckebusch and P. Thivend, editors]. Lancaster: MTP Press Ltd.

Bell, F. R. \& McLeay, L. M. (1978). F. Physiol., Lond. 282, 51 .

Bell, F. R. \& Mostaghni, K. (1975). F. Physiol., Lond. 245, 387.

Besle, J. M. \& Thivend, P. (1980). Reprod. Nutr. Dévelop. $20, \mathrm{I} 849$.

Bueno, I. \& Fioramonti, J. (1979). In Digestive Physiology and Metabolism in Ruminants, p. 53

[Y. Ruckebusch and P. Thivend, editors]. Lancaster: MTP Press Ltd.

Bueno, L., Fioramonti, J. \& Ruckebusch, Y. (1975). f. Physiol., Lond. 249, 69.

Bush, L. J., Schuh, J. D., Tennille, N. B. \& Waller, G. R. (1963). F. Dairy Sci. 46, 703.

Circle, S. J. \& Smith, A. K. (1972). In Soyabeans: chemistry and technology vol. 1. proteins, p. 294 [A. K. Smith and S. J. Circle, editors]. Connecticut: The Avi Pub. Co. Inc.

Cook, C. D. (1960). New Engl. Y. Med. 263, 1076.

Coombe, N. B. (1972). Carbohydrate digestion and absorption in the preruminant calf, PhD Thesis, University of Reading.

Dardillat, C. (1977). F. Physiol., Paris 73, 925.

Dardillat, C. \& Marrero, E. (1977). Ann. Biol. anim. Bioch. Biophys. 1 7, 523.

de Muelenaere, H. J. H. (1964). F. Nutr. 82, 197 .

Erbersdobler, H. (1973). In Protein in Human Nutrition, p. 453 (J. W. G. Porter \& B. A. Rolls, editors]. London: Acad. Press.

Fries, G. F., Lassiter, C. A. \& Huffman, C. F. (1958). F. Dairy Sci. 41, 108 I.

Garnot, P., Toullec, R., Thapon, J. L., Martin, M., Hang, M-T., Mathieu, C. M. \& RibadeauDumas, B. (1977). J. Dairy Res. 44, 9.

Gertler, A. \& Nitsan, Z. (1970). Br. F. Nutr. 24, 893 .

Glaser, J. \& Johnstone, D. E. (1953). Ann. Allergy. 10, 433.

Gorrill, A. D. L. \& Nicholson, J. W. G. (1969). Can. F. Anim. Sci. 49, 315.

Gorrill, A. D. L. \& Nicholson, J. W. G. (1972). Can. J. Anim. Sci. 52, $46_{5}$.

Gorrill, A. D. L. \& Thomas, J. W. (1967). F. Nutr. 9z, 215.

Gorrill, A. D. L., Thomas, J. W., Stewart, W. E. \& Morrill, J. L. (I g67). F. Nutr. 92, 86.

Gunn, R. A., Taylor, P. R. \& Gangarosa, E. J. (1980). Y. Fd Protection 43, 525.

Henschel, M. J. (1973). Br. F. Nutr. 30, 285.

Hunt, J. N. \& Knox, M. T. (1968). In Handbook of Physiology, section 6: Alimentary Canal vol. iv motility, p. 1917 [C. F. Code, editor]. American Physiology Society.

Jarrett, E. E. E. (1973). Vet. Rec. 93, 480 .

Jarrett, E. E. E. \& Urquhart, G. M. (1971). Int. Rev. Trop. Med. 4, 216.

Kilshaw, P. J. \& Sissons, J. W. (1979a). Res. Vet. Sci. 27, 36 1.

Kilshaw, P. J. \& Sissons, J. W. (1979b). Res. Vet. Sci. 27, 366.

Kilshaw, P. J. \& Slade, H. (1980). Clin. exp. Immunol. 41, 575.

Kwiatkowska, A. (1973). Prace i Materialy Zootech. 3, 63 .

Lassiter, C. A., Fries, G. F., Huffman, C. F. \& Duncan, C. W. (1959). J. Dairy Sci. 42, 666.

Mortimer, E. Z. (1959). gth Int. Cong. Paediatrics, Montreal, July, 1959.

Nitsan, Z., Volcani, R., Gordin, S. \& Hasdai, A. (1971). F. Dairy Sci. 54, 1294.

Nitsan, Z., Volcani, R., Hasdai, A. \& Gordin, S. (1972). F. Dairy Sci. 55, 81 r.

Perlman. F. (1966). Fd Technol. 20, 1438.

Polak, J. M. \& Bloom, S. R. (1980). In Gastrointestinal Hormones, p. 19 [G. B. J. Glass, editor]. New York: Raven Press.

Poncet, C., Dimova, E., Leveille, M. \& Dardillat, C. (1977). Anim. Biol. anim. Bioch. Biophys. 17,515 .

Quigley, J. P. \& Mescham, I. (1941). Am. F. Physiol. 134, 803.

Rackis, J. J. (I g66). $\}$. Fd Technol. 20, I02.

Rackis, J. J., Honig, D. H., Sessa, D. J. \& Steggerda, F. R. (1970). J. Agric. Fd Chem. I8, 977 .

Rackis, J. J., Smith, A. K., Nash, A. M., Robbins, D. J. \& Booth, A. N. (1963). Cereal Chem. 40, 531 .

Ratner, B., Untracht, S., Crawford, L. V., Malone, J. H. \& Retsina, M. (1955). Am. F. Dis. Child. 89,187 .

Raven, A. M. (1970). F. Sci. Fd Agric. 21, 352. 
Roitt, I. M. (1974). In Essential Immunology, p. 129 [I. M. Roitt, editor]. London: Blackwell Scientific Publications.

Roy, J. H. B., Stobo, I. J. F., Shotton, S. M., Ganderton, P. \& Gillies, C. M. (1977). Br. f. Nutr. 38,167 .

Ruckebusch, Y. \& Bueno, L. (1973). Br. J. Nutr. 30, 491.

Sellars, W. A., Helpern, S. R., Johnson, R. B., Anderson, D. W., Saperstein, S. \& Shannon, B. S. (1971). Ann. Allergy 29, 126.

Shoptaw, L. (1936). F. Dairy Sci. 19, 95.

Siddons, R. C. (1 968$)$. Biochem. $\mathcal{J} .108,839$.

Sissons, J. W. \& Smith, R. H. (1976). Br. F. Nutr. 36, 42 I.

Sissons, J. W. \& Smith, R. H. (1978). F. Physiol., Lond. 283, 307.

Sissons, J. W. \& Smith, R. H. (1979). Ann. Res. Vet. 10, 176.

Sissons, J. W., Smith, R. H. \& Hewitt, D. (1979). Br. F. Nutr. 42, 477.

Sissons, J. W., Smith, R. H. \& Nyrup, A. (198I). Proc. Nutr. Soc. 41, i I A.

Smith, R. H. (1963). Nature, Lond. 198, 16I.

Smith, R. H. (1 966). F. Physiol., Lond. 183, 532.

Smith, R. H. \& Sissons, J. W. (1975). Br. F. Nutr. 33, 329.

Stead, R. H., de Meulenaere, H. J. H. \& Quicke, G. V. (I966). Arch. Biochem. Biophys. I 13, 703.

Steggerda, F. R., Richards, E. A. \& Rackis, J. J. (1966). Proc. Soc. exp. Biol. Med. 121, 1235.

Stein, J. F., Knott, C. B. \& Rose, E. B. (1954). Y. Dairy Sci. 37, 373.

Stephens, J. R., Woolson, R. F. \& Cooke, A. R. (1975). Gastroenterology 69, 920.

Szurszewski, J. H. (1969). Am. f. Physiol. 217 , 757.

Tagari, H. \& Roy J. H. B. (1969). Br. Y. Nutr. 23, 763 .

Ternouth, J. H., Roy, J. H. B., Thompson, S. Y., Toothill, J., Gillies, C. M. \& Edwards-Webb, J. D. (1975). Br. F. Nutr. 33, I81.

Ternouth, J. H., Siddons, R. C. \& Toothill, J. (1971). Proc. Nutr. Soc. 30, 89 A.

Thomas, J. E. (1942). Am. J. Physiol. r 35, 609 .

van Leeuwen, J. M, Weide, H. J. \& Braas, C. C. (1969). Versl. landbouwk. Onderz. Ned. no. 732.

Vest, M. (1953). Ann. Paediat. 181, 277.

Vest, M., Olafson, A. \& Schenkar, P. (I966). Schweiz. med. Wschr. 96, 762.

Williams, J. B. \& Knodt, C. B. (1950). F. Dairy Sci. 33, 809.

Williams, J. B. \& Knodt, C. B. (1951). F. Anim. Sci. ro, 975.

Williams, V. J., Roy, J. H. B. \& Gillies, C. M. (1976). Br. $\mathscr{f}$. Nutr. 36, $3^{1} 7$

Wolf, W. J. (1 970). F. Agric. Fd Chem. 18, 969. 